\title{
Asthma and allergic disease prevalence in a diverse sample of Toronto school children: Results from the Toronto Child Health Evaluation Questionnaire (T-CHEQ) Study
}

\author{
Sharon D Dell MD¹, Richard G Foty $\mathrm{MSc}^{1}$, Nicolas L Gilbert $\mathrm{MSc}^{3}$, Michael Jerrett $\mathrm{PhD}^{4}$, \\ Teresa To $\mathrm{PhD}^{1}$, Stephen D Walter $\mathrm{PhD}^{2}$, David M Stieb MD ${ }^{3}$
}

\begin{abstract}
SD Dell, RG Foty, NL Gilbert, et al. Asthma and allergic disease prevalence in a diverse sample of Toronto school children: Results from the Toronto Child Health Evaluation Questionnaire (T-CHEQ) Study. Can Respir J 2010;17(1):e1-e6.
\end{abstract}

BACKGROUND: Asthma is the most common chronic disease in children. OBJECTIVES: To describe the prevalence of asthma and allergic disease in a multiethnic, population-based sample of Toronto (Ontario) school children attending grades 1 and 2 .

METHODS: In 2006, the Toronto Child Health Evaluation Questionnaire (T-CHEQ) used the International Study of Asthma and Allergies in Childhood survey methodology to administer questionnaires to 23,379 Toronto school children attending grades 1 and 2. Modifications were made to the methodology to conform with current privacy legislation and capture the ethnic diversity of the population. Lifetime asthma, wheeze, hay fever and eczema prevalence were defined by parental report. Asthma was considered to be current if the child also reported wheeze or asthma medication use in the previous 12 months.

RESULTS: A total of 5619 children from 283 randomly sampled public schools participated. Children were five to nine years of age, with a mean age of 6.7 years. The overall prevalence of lifetime asthma was $16.1 \%$, while only $11.3 \%$ had current asthma. The reported prevalence of lifetime wheeze was $29.2 \%$, while $14.2 \%$ reported wheeze in the past 12 months. Sociodemographic and major health determinant characteristics of the T-CHEQ population were similar to 2001 census data, suggesting a diverse sample that was representative of the urban childhood population.

CONCLUSIONS: Asthma continues to be a highly prevalent chronic disease in Canadian children. A large proportion of children with reported lifetime asthma, who were five to nine years of age, did not report current asthma symptomatology or medication use.

Key Words: Childhood asthma; Epidemiology; Survey research
La prévalence d'asthme et de maladies allergiques dans un échantillon diversifié d'enfants d'âge scolaire de Toronto : Les résultats de l'étude au moyen du questionnaire d'évaluation de la santé des enfants de Toronto (T-CHEQ)

HISTORIQUE : L'asthme est la principale maladie chronique chez les enfants. OBJECTIFS : Décrire la prévalence de l'asthme et des maladies allergiques dans un échantillon multiethnique en population d'enfants de première et deuxième années de Toronto, en Ontario.

MÉTHODOLOGIE : En 2006, les auteurs ont utilisé un questionnaire d'évaluation de la santé des enfants de Toronto (T-CHEQ) faisant appel à la méthodologie de l'enquête internationale sur l'asthme et les allergies pendant l'enfance pour interroger 23379 enfants de première et deuxième années de Toronto. Ils ont modifié la méthodologie pour respecter les lois à jour sur le respect de la vie privée et déterminer la diversité ethnique de la population. La prévalence d'asthme, de respiration sifflante, de rhume des foins et d'eczéma à vie était définie selon les déclarations des parents. L'asthme était considéré comme actif si l'enfant déclarait également avoir eu une respiration sifflante ou avoir pris des médicaments contre l'asthme au cours des 12 mois précédents. RÉSULTATS : Au total, 5619 enfants provenant de 283 écoles publiques choisies au hasard ont participé. Les enfants, d'un âge moyen de 6,7 ans, avaient de cinq à neuf ans. La prévalence globale d'asthme à vie était de $16,1 \%$, mais seulement $11,3 \%$ avaient alors des symptômes d'asthme. La prévalence déclarée de respiration sifflante à vie s'élevait à 29,2\%, tandis que seulement $14,2 \%$ déclaraient avoir eu une respiration sifflante au cours des 12 mois précédents. Les caractéristiques démographiques et les principaux déterminants de la santé de la population ayant répondu au T-CHEQ étaient similaires aux données du recensement de 2001, indiquant un échantillon diversifié représentatif de la population urbaine d'enfants.

CONCLUSIONS : L'asthme continue d'être une maladie chronique fortement prévalente chez les enfants canadiens. Une forte proportion d'enfants de cinq à neuf ans ayant toujours été atteints d'asthme déclaré n'avaient pas de symptomatologie courante d'asthme ou n'utilisaient pas de médicaments.

Caucasian. Comparisons of asthma prevalence rates in different geographical regions and over time may help to identify risk factors that contribute to the inception of asthma.

Using the Toronto Child Health Evaluation Questionnaire (T-CHEQ), the aim of the current study was to describe the prevalence of asthma and asthma symptoms among children attending grades 1 and 2 in publicly funded schools in Toronto, Ontario. Toronto is a multiethnic urban centre, with a population of 2.5 million and a large new immigrant population (50\% foreign born in 2006 [16]). The present population-based study, funded by Health Canada, used the ISAAC methodology in an urban, diverse and multiethnic setting, where more than $80 \%$ of Canadian children currently reside. the childhood population in these cities was predominantly

\footnotetext{
${ }^{1}$ The Hospital for Sick Children, Toronto; ${ }^{2}$ Department of Clinical Epidemiology and Biostatistics, McMaster University, Hamilton;

${ }^{3}$ Health Canada, Ottawa, Ontario; ${ }^{4}$ University of California, Berkeley, California, USA

Correspondence: Dr Sharon Dell, The Hospital for Sick Children, 555 University Avenue, Toronto, Ontario M5G 1 X8.

Telephone 416-813-6248, fax 416-813-6246, e-mail Sharon.dell@sickkids.ca
} 


\section{METHODS}

The T-CHEQ Study was a multistage, cross-sectional study designed to collect population-based prevalence data regarding asthma, other allergic diseases and possible associated risk factors in Toronto school children attending grades 1 and 2 during the winter of 2006. In the first phase of the study, parents were asked to complete a $20 \mathrm{~min}$, self-administered questionnaire about the health of their child. In addition to the ISAAC core questions on asthma, rhinitis and eczema, the T-CHEQ used a detailed medication use question that was developed by the study investigators in a previous epidemiological study (17). The T-CHEQ was field tested in six schools in the winter of 2005 to establish study design feasibility and to further refine the questionnaire. Data from the pilot study are not included in the present article.

The methods of sample selection, recruitment procedures and data collection followed the recommended ISAAC study methodology (18) as much as possible, with some modifications (described below) necessary to comply with new Canadian federal privacy legislation, and to adapt it to Toronto's multiethnic urban setting. Twenty-one research assistants of diverse ethnicity and language abilities recruited schools for participation. Schools were selected by use of a random number generator from a pool of 556 eligible schools within the two publicly funded school boards in Toronto (Toronto District School Board and the Toronto Catholic District School Board), which accommodate nearly $90 \%$ of the elementary school population in Toronto (19). A designated research assistant (matched to the school on major ethnic group if possible) contacted each randomly selected school to obtain permission from the principal for questionnaire distribution to the children. If the school principal refused permission, that school was replaced with the next randomly selected school until a sample size of 20,000 children was reached. The self-administered parent questionnaire was sent home with all students attending grades 1 and 2 in each participating school. Whenever allowed, the research assistants delivered a 5 min classroom presentation describing the study to the children. The five most common primary languages spoken by students were reported by each school board. A cover letter explaining the purpose of the study was translated into these languages, plus any additional predominant languages for each individual school identified by the principal, and accompanied the English language T-CHEQ questionnaire.

If a participant did not speak English, they were asked to complete the questionnaire with the help of an English-speaking family member or friend, or to contact the research coordinator for translation services. Translation services (via a three-way teleconference between the study coordinator, translator and participant) were available to all those who required assistance. A second distribution of questionnaires was made to all children two to three weeks after the first distribution. Recent new federal privacy legislation forbids access to classroom name lists to aid in directed recruitment procedures. To have the most accurate information for questionnaire distribution and response-rate calculations, the total number of grade 1 and two students currently registered in each school was provided by the school principal. Completed questionnaires were either returned to the school in person or mailed directly to the T-CHEQ study team using a self-addressed, stamped envelope.
The questionnaires were printed on a computer-scannable form. All returned surveys were checked by research assistants for stray marks and errors that could impede computer scanning. To improve data accuracy, the questionnaires were scanned twice; any discrepancies in data agreement were manually resolved, if possible, or replaced with a missing value. Once the full data set was obtained, it was systematically 'data cleaned' using algorithms to replace impossible or extreme values of variables with a missing data point.

Questions defining variables related to demographics and asthma or allergic symptoms and disease were transcribed directly from either the ISAAC questionnaires (for asthma and allergy outcomes and risk factors) (15), or Canadian national surveys (including individual level household income, education, dwelling type, household size and environmental tobacco smoke exposure) $(20,21)$ to enable national and international comparisons of the data. 'Lifetime asthma' was defined as an affirmative response to the question "Has your child ever had asthma"? 'Doctor-diagnosed lifetime asthma' also required an affirmative response to the question "Was this diagnosed by a doctor"? 'Current asthma' was a derived variable defined as doctor-diagnosed lifetime asthma and report of wheeze and/or taking medication(s) for asthma or wheezing in the past 12 months. Lifetime hayfever and eczema were defined by affirmative responses to core ISAAC questions: "Has your child ever had hayfever"? and "Has your child ever had eczema?", respectively, with a subsequent question restricting the disease to being doctor diagnosed. Detailed information regarding medication use for asthma or wheeze in the previous 12 months was parentreported, with the aid of a coloured chart, which included pictures of all currently labelled asthma medications available in Canada.

Data regarding ethnicity were not collected at the individual level. However, school board-level data on the five most common languages (other than English) spoken by children, and individual school data on percentage of students speaking English as a second language, were collected from the school board databases.

All statistics were computed using SAS version 9.1 (SAS Inc, USA). School- and individual-level response rates were calculated using denominators of the total number of eligible schools approached and the total number of grade 1 and 2 students in each participating school, respectively. The target sample size of 20,000 was calculated to yield risk estimates of environmental exposures that would be significantly precise to be explored in future analyses. The prevalence rates calculated took into account missing responses for each variable. Many T-CHEQ participants were from the same school. Schools, therefore, may also be viewed as clusters of students. There may exist some characteristics that are common to all children in one school and differentiates them from those in others. To account for possible school clustering effects, prevalence and 95\% CIs were calculated using the cluster option of the SURVEYFREQ procedure, which identifies each school as a cluster of students. To evaluate the representativeness of the sample, data on demographic, health determinant and asthma outcome variables from two national surveys were obtained: the 2001 census, which had at least one child five to 17 years of age (essentially a $100 \%$ response rate because participation is mandatory), and Cycle 4 (2000/2001) of the National 


\begin{tabular}{|c|c|c|c|c|}
\hline & \multicolumn{2}{|c|}{ Toronto District School Board } & \multicolumn{2}{|c|}{ Toronto Catholic District School Board } \\
\hline & Participated & Refused & Participated & Refused \\
\hline School student population & $436(151-1470)$ & 509 (162-1189) & $369(131-748)$ & $350(137-516)$ \\
\hline Grades 1 and 2 population & $100(31-437)$ & $109(40-280)$ & NA & NA \\
\hline English not primary language, \% & 48 & 48 & 54 & 59 \\
\hline \multicolumn{5}{|c|}{ Top languages spoken at home, as reported by school board } \\
\hline & French & NA & French & NA \\
\hline & Spanish & & Spanish & \\
\hline & Traditional & & Traditional & \\
\hline & Chinese & & Chinese & \\
\hline & Tamil & & Tamil & \\
\hline & Urdu & & Portuguese & \\
\hline & Somali & & Ukrainian & \\
\hline & Vietnamese & & Polish & \\
\hline \multicolumn{5}{|c|}{ Additional languages reported by individual schools } \\
\hline & Farsi & & & \\
\hline & Hindi & & & \\
\hline & Bengali & & & \\
\hline & Greek & & & \\
\hline
\end{tabular}

Data are presented as median (range), unless indicated otherwise. NA Not available

Longitudinal Survey of Children and Youth (NLSCY), restricted to children five to nine years of age $(22,23)$. The NLSCY is a voluntary childrens health survey conducted by Statistics Canada, with an $84.8 \%$ household response rate. The NLSCY uses the same ISAAC questions to ascertain asthma and wheeze prevalence as the T-CHEQ survey. The census and NLSCY data were restricted to households in the Toronto census metropolitan area for comparability purposes. The Toronto metropolitan census area extends beyond the T-CHEQ geographical borders and includes a slightly higher proportion of the suburban population.

Ethics approval was obtained from both The Hospital for Sick Children (Toronto, Ontario) and the Health Canada Research Ethics Boards. Permission to conduct the T-CHEQ study in the schools was obtained first from the Toronto District and Catholic School Boards' research committees, followed by permission from each school's principal. The T-CHEQ cover letter sent to parents explained that parental consent was implied by completing and returning the questionnaire.

\section{RESULTS}

Between January and April 2006, 231 of the 556 eligible elementary schools in Toronto participated. The school response rate was $80 \%$ (231 of 283 randomly selected schools that were approached). In total, 5619 completed questionnaires were returned from a population of 23,379 grades 1 and 2 school children, resulting in an individual-level response rate of $25 \%$. Of these, 3289 (60\%) responded directly to the T-CHEQ team by mail and $2180(40 \%)$ were returned in person, through the schools (data for 150 of the method of return variable were missing). Forty participants used the study-supplied translation services. Overall, the frequency of missing data was very low (less than $3 \%$ for most variables). The income variable had the highest rate of missing data $(6.7 \%)$.

The multiethnic characteristics of the schools sampled are shown in Table 1, 49\% of children in participating schools reported speaking English as a second language. In 20 schools
(9\% of participating schools), more than $75 \%$ of students reported speaking English as a second language. The participating schools were no different from the nonresponding schools in terms of school size or per cent speaking English as a second language.

Table 2 shows the demographic characteristics of individual participants. The average age of T-CHEQ participants was 6.74 years, approximatley one-half were male and $76 \%$ were born in Canada. Slightly less than $50 \%$ of the responding parents reported having a university education and 37\% were in the highest level of income adequacy as defined by Statistics Canada (based on total household income and number of people in the household).

The overall prevalence of lifetime asthma was $16.1 \%$ (Table 3), 96\% of which was reported to have been diagnosed by a doctor. Only $11.3 \%$ had current asthma. Lifetime hay fever and doctor-diagnosed hay fever were reported by $15.8 \%$ and $10.2 \%$ of respondents, respectively. Of the $24.3 \%$ of respondents who reported having eczema, $88 \%$ had been diagnosed by a doctor. The prevalence of both lifetime asthma and current asthma was higher among males than females $(19.8 \%$ versus $12.6 \%$, and $14.2 \%$ versus $8.5 \%$, respectively) (Table 4 ). Males also showed a higher prevalence of symptoms than females, including lifetime and current wheeze and rhinitis. There was no statistical difference between males and females in the prevalence of eczema or doctor-diagnosed hayfever. Significant clustering effects by school in any of the asthma and allergy outcome variables were absent.

\section{DISCUSSION}

The high overall lifetime asthma prevalence of $16.1 \%$ found in the present study is similar to results from other developed countries (13). It is also similar to the asthma prevalence reported in the only other Canadian study using ISAAC methodology in the same age group conducted in two cities (Hamilton, Ontario, and Edmonton, Alberta): $17.2 \%$ in $1994 / 1995$ (12) and $18.2 \%$ in 2002/2003 (13). The NLSCY, 
TABLE 2

Toronto Child Health Evaluation Questionnaire (T-CHEQ) participant characteristics $(n=5619)$ compared with the National Longitudinal Survey of Children and Youth (NLSCY), Cycle 4 data

\begin{tabular}{|c|c|c|c|}
\hline \multirow[b]{2}{*}{ Variable } & \multicolumn{2}{|c|}{ T-CHEQ* } & \multirow{2}{*}{$\frac{\text { NLSCY }}{n(\%)}$} \\
\hline & n (\%) & $95 \% \mathrm{Cl}$ & \\
\hline Male sex $(n=5572)$ & $2772(49.7)$ & $48.3-51.2$ & $122,700(50.8)^{\dagger}$ \\
\hline \multicolumn{4}{|c|}{ Income adequacy $\ddagger(n=5240)$} \\
\hline Lowest & 935 (17.8) & $15.3-20.4$ & $55,870(11.3)^{\dagger}$ \\
\hline Lower middle & $1160(22.1)$ & $19.6-24.6$ & $82,769(16.7)^{\dagger}$ \\
\hline Upper middle & $1201(23.0)$ & $21.2-24.6$ & $140,526(28.4)^{\dagger}$ \\
\hline Highest & 1945 (37.1) & $31.9-42.3$ & $215,192(43.5)^{\dagger}$ \\
\hline \multicolumn{4}{|c|}{ Highest level of education $(n=5361)^{\S}$} \\
\hline $\begin{array}{l}\text { Elementary/ } \\
\text { secondary only }\end{array}$ & $1074(20.0)$ & $17.7-22.4$ & NA \\
\hline $\begin{array}{l}\text { College education } \\
\text { only }\end{array}$ & $1841(34.3)$ & $32.4-36.3$ & NA \\
\hline University & $2446(45.6)$ & $42.1-49.1$ & NA \\
\hline $\begin{array}{l}\text { Child born in Canada } \\
\qquad(n=5585)\end{array}$ & $4250(76.1)$ & $72.8-79.4$ & NA \\
\hline \multicolumn{4}{|c|}{ Type of dwelling $(n=5344)$} \\
\hline Single & $2406(45.8)$ & $41.1-50.4$ & $273,430(54.9)^{\dagger}$ \\
\hline $\begin{array}{l}\text { Semidetached or } \\
\text { row house }\end{array}$ & 1039 (19.8) & $17.1-22.5$ & $98,531(19.8)^{\dagger}$ \\
\hline $\begin{array}{l}\text { Duplex or lowrise } \\
\text { apartment }\end{array}$ & $446(8.5)$ & $7.3-9.6$ & $35,039(7.04)^{\dagger}$ \\
\hline $\begin{array}{l}\text { Highrise apartment } \\
\text { ( } \geq 5 \text { stories) }\end{array}$ & $1368(26.0)$ & $21.4-30.6$ & $89,910(18.06)^{\dagger}$ \\
\hline \multicolumn{4}{|c|}{ Household size $(n=5541)$} \\
\hline 2 & $166(3.0)$ & $2.5-3.5$ & $24,975(5.0)^{\dagger}$ \\
\hline 3 & $983(17.7)$ & $16.2-19.2$ & $91,760(18.4)^{\dagger}$ \\
\hline 4 & $2434(43.9)$ & $42.0-45.8$ & $207,163(41.6)^{\dagger}$ \\
\hline$\geq 5$ & $1958(35.3)$ & $33.5-37.2$ & $173,715(34.9)^{\dagger}$ \\
\hline $\begin{array}{l}\text { Environmental } \\
\text { tobacco smoke }{ }^{\dagger} \\
(n=5600)\end{array}$ & $630(11.3)$ & $10.2-12.3$ & $49,800(21.1)^{\pi}$ \\
\hline
\end{tabular}

${ }^{*} T$-CHEQ sample size excludes missing data. 'Statistics Canada, special tabulation, unpublished data, Canada census, 2001 ( $n=13,368$ households); ¥Income adequacy is a derived variable defined by Statistics Canada as total household income adjusted for the number of persons in the household. Lowest income: $<\$ 15,000,1-2$ or $<\$ 20,000,3-4$ or $<\$ 30,000, \geq 5$; Lower middle income: $\$ 15,000$ to $\$ 29,999,1-2$, or $\$ 20,000$ to $\$ 39,999$, 3-4, or $\$ 30,000$ to $\$ 59,999, \geq 5$; Upper middle income: $\$ 30,000$ to $\$ 59,999$, $1-2$, or $\$ 40,000$ to $\$ 79,999,3-4$, or $\geq \$ 60,000,1-2$, or $\geq \$ 80,000$, $\geq 3$; Highest income:

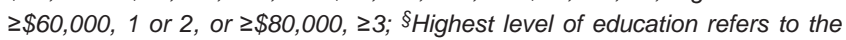
reporting parent. "Statistics Canada, special tabulation, unpublished data, NLSCY, Cycle 4 (2000-2001) $(n=241,300)$ (22). NA Not available

which samples children through a national, population-based, household sampling strategy, showed an asthma prevalence of $16.7 \%$ in children five to nine years of age in 2000 to 2001. The results of these studies, although not directly comparable, suggest that Canada may have experienced a plateau in asthma prevalence over the past decade, similar to other developed countries $(6,7)$.

Interestingly, a large proportion (30\%) of the children with reported lifetime asthma do not have current symptomatology
TABLE 3

Major health determinant characteristics of the Toronto Child Health Evaluation Questionnaire (T-CHEQ) population and comparisons with the National Longitudinal Survey of Children and Youth (NLSCY), Cycle 4 data

\begin{tabular}{|c|c|c|c|}
\hline \multirow[b]{2}{*}{ Variable } & \multicolumn{2}{|c|}{$\begin{array}{l}\text { T-CHEQ* } \\
(n=5619)\end{array}$} & \multirow{2}{*}{$\begin{array}{c}\begin{array}{c}\mathrm{NLSCY}^{\dagger} \\
(\mathrm{n}=241,300)\end{array} \\
\mathrm{n}(\%)\end{array}$} \\
\hline & n (\%) & $95 \% \mathrm{Cl}$ & \\
\hline $\begin{array}{l}\text { Lifetime asthma } \\
\qquad(\mathrm{n}=5475)\end{array}$ & $883(16.1)$ & $15.0-17.2$ & $40,200(16.7)$ \\
\hline $\begin{array}{l}\text { Doctor-diagnosed } \\
\text { lifetime asthma } \\
(n=5461)\end{array}$ & $847(15.5)$ & $14.4-16.6$ & NA \\
\hline $\begin{array}{l}\text { Current asthma } \\
(\mathrm{n}=5464)^{\ddagger}\end{array}$ & $619(11.3)$ & $10.4-12.3$ & NA \\
\hline $\begin{array}{l}\text { Lifetime wheeze } \\
\qquad(\mathrm{n}=5570)\end{array}$ & $1627(29.2)$ & 27.5-30.9 & NA \\
\hline $\begin{array}{l}\text { Wheeze in the past } \\
12 \text { months }(n=5559)\end{array}$ & $790(14.2)$ & $13.1-15.3$ & $34,400(14.3)$ \\
\hline \multicolumn{4}{|c|}{ Attacks of wheeze in the past 12 months $(n=5549)$} \\
\hline $1-3$ & $575(10.4)$ & $9.4-11.3$ & NA \\
\hline $4-12$ & $135(2.4)$ & $2.0-2.8$ & NA \\
\hline$>12$ & $38(0.7)$ & $0.5-0.9$ & NA \\
\hline \multicolumn{4}{|c|}{ Sleep disturbances due to wheeze, nights per week $(n=5548)$} \\
\hline$<1$ & $310(5.6)$ & $5.0-6.2$ & NA \\
\hline$\geq 1$ & $108(1.9)$ & $1.6-2.3$ & NA \\
\hline $\begin{array}{l}\text { Speech limitation due } \\
\text { to wheeze }(n=5548)\end{array}$ & $103(1.9)$ & $1.5-2.2$ & NA \\
\hline $\begin{array}{l}\text { Lifetime rhinitis } \\
\qquad(n=5550)\end{array}$ & 1335 (24.1) & 22.9-25.2 & NA \\
\hline $\begin{array}{l}\text { Rhinitis in the past } \\
12 \text { months }(n=5360)\end{array}$ & $1145(21.4)$ & $20.2-22.5$ & NA \\
\hline $\begin{array}{l}\text { Lifetime hay fever } \\
\qquad(\mathrm{n}=5523)\end{array}$ & $870(15.8)$ & $14.6-16.9$ & NA \\
\hline $\begin{array}{l}\text { Doctor-diagnosed } \\
\text { hay fever }(n=5184)\end{array}$ & $531(10.2)$ & $9.2-11.3$ & NA \\
\hline $\begin{array}{l}\text { Lifetime eczema } \\
\qquad(\mathrm{n}=5503)\end{array}$ & $1337(24.3)$ & $22.8-25.8$ & NA \\
\hline $\begin{array}{l}\text { Doctor-diagnosed } \\
\text { eczema }(n=5493)\end{array}$ & 1177 (21.4) & $20.1-22.7$ & NA \\
\hline
\end{tabular}

${ }^{*}$ T-CHEQ sample size excludes missing data. ${ }^{\dagger}$ Statistics Canada, special tabulation, unpublished data (2000 to 2001) (21); ${ }^{\ddagger}$ Current asthma is a derived variable defined as those who report having been diagnosed with asthma by a doctor and either wheeze or taking medications for asthma or wheeze within the past 12 months. NA Not available

or medication use at the age of six to seven years; only $11.3 \%$ of the children have current asthma, while $15.5 \%$ have lifetime doctor-diagnosed asthma. Asthma is a clinical diagnosis in the preschool years that is based mainly on the symptom of wheeze. It is highly likely that many children labelled with 'asthma' in the preschool years have transient viral wheezing that they will 'outgrow' by school age (24). The discrepancy between lifetime asthma prevalence and current asthma symptoms has been previously described (12). Our data are also consistent with other asthma prevalence studies in showing a male predominance in both asthma and wheeze prevalence (12) in children younger than 15 years of age. 
We further restricted the prevalence of asthma, hay fever and eczema to those diagnosed by a doctor. Because all children in Canada have access to physician services, one would expect most reported asthma cases to be doctor-diagnosed, which is indeed the case $(97 \%$ of lifetime asthma was reported to be doctor diagnosed). Interestingly, only $88 \%$ of eczema cases and $61 \%$ of hay fever cases were reported to be doctor diagnosed.

The main strengths of the T-CHEQ study are its large sample size, its population-based, multiethnic, urban sampling and recruiting strategy and the use of a visual guide to gather medication information. Use of the ISAAC questionnaire in developing the T-CHEQ study enables results to be easily compared with international studies using the same standardized methodology. The ISAAC questionnaire is a validated survey tool that has been shown to have better sensitivity and specificity than bronchial hyper-responsiveness testing in measuring asthma prevalence within a population $(25,26)$. The addition of a restriction variable to include current symptomatology (ie, within the previous year) is well accepted in the asthma epidemiological literature (27). The ISAAC questionnaire has yet to be validated in Canada, although we would expect results to be similar to those found in other developed countries with a public health care system such as Australia (25). Authors of this study are currently conducting a direct measures study with a subsample of the T-CHEQ population to validate the ISAAC questionnaire against physician diagnosis and bronchial hyperresponsiveness testing.

Although 5619 respondents participated in the T-CHEQ study, the individual-level response rate was only $25 \%$. Similar ISAAC study methods in schools yielded a response rate of $80 \%$ in 1994 (12) and 60\% in 2001 (13), in two other Canadian cities. Since 1994, many factors have changed in Canadian society that would be expected to affect response rates, including public attitudes about participating in research, privacy legislation - which does not allow for targeted recruitment procedures - the perceived role of the school in public health research versus education and the large influx of a heterogeneous non-English speaking immigrant population to urban centres. Clearly, the low response rate of the present study challenges the representativeness of the grade 1 and 2 Toronto student population and, ultimately, the generalizability of the results. Generally, a response rate of $70 \%$ is required in epidemiological studies reporting prevalence rates to ensure a representative sample. In addition, one wonders whether the ISAAC school sampling methodology is now obsolete and, if so, how one can obtain accurate estimates of current childhood asthma prevalence. To determine the generalizability of the T-CHEQ study sample, results were compared with national surveys considered to be representative of the Canadian population at large. Data from the 2001 Canadian census showed similar income adequacy levels, household size and housing characteristics to the T-CHEQ study (Table 2). The NLSCY found the overall prevalence of asthma to be $16.7 \%$ in 2001 compared with $16.1 \%$ in the T-CHEQ survey. In the same group of children, the NLSCY also found that $21.1 \%$ of participants were exposed to environmetal tobacco smoke (ETS) in the home compared with $11.2 \%$ of children in the T-CHEQ survey (Table 2). Differences in ETS exposure between the T-CHEQ and the NLSCY are likely due to different wording of the questions used to ascertain ETS exposure

\section{TABLE 4}

Prevalence of asthma and asthma-like symptoms according to sex $(n=5619)$

\begin{tabular}{|c|c|c|c|}
\hline \multirow[b]{2}{*}{ Variable } & \multicolumn{2}{|c|}{ Prevalence, \% } & \multirow[b]{2}{*}{$\mathbf{P}$} \\
\hline & Male & Female & \\
\hline Lifetime asthma & 19.8 & 12.6 & $<0.0001$ \\
\hline Doctor-diagnosed lifetime asthma & 19.1 & 12.0 & $<0.0001$ \\
\hline Current asthma & 14.2 & 8.5 & $<0.0001$ \\
\hline Lifetime wheeze & 33.7 & 24.8 & $<0.0001$ \\
\hline Wheeze in the past 12 months & 16.7 & 11.8 & $<0.0001$ \\
\hline Lifetime rhinitis & 27.2 & 21.0 & $<0.0001$ \\
\hline Rhinitis in the past 12 months & 24.5 & 18.3 & $<0.0001$ \\
\hline Lifetime hayfever & 16.2 & 15.2 & 0.33 \\
\hline Doctor-diagnosed hay fever & 10.7 & 9.8 & 0.28 \\
\hline Lifetime eczema & 24.7 & 23.9 & 0.52 \\
\hline Doctor-diagnosed eczema & 21.9 & 20.9 & 0.37 \\
\hline
\end{tabular}

(T-CHEQ confined ETS questions to smoking inside the house while the NLSCY asks whether a parent in the household smokes) and/or the timing of the surveys. A large public health campaign and new legislation introduced in 2001 aimed to decrease second-hand ETS exposure to the public as well as to children. Because important demographic (sex, income, dwelling type and household size) and health indicator data (asthma and wheeze prevalence, and ETS exposure) in the T-CHEQ study are similar to the above mentioned census data and national surveys, we are relatively confident that the participants of the T-CHEQ study constitute a representative sample of the school children attending grades 1 and 2, although we must still caution interpretation of our results given the low response rate. In our attempt to prevent selection bias in sampling, we avoided the use of the words 'asthma' and 'allergy' in our recruitment cover letter. However, the possibility of selection bias remains, which could lead to an overestimation of prevalence rates.

Another limitation of our study was that we only offered the written survey in English. Although the cover letter was translated into the most commonly spoken languages of each school and we offered telephone translation services on the cover letter to allow non-English speaking parents to participate in the study, very few participants actually used this service. We suspect that many non-English speaking parents used the help of family members, friends or neighbours to complete the survey in English. Because it is widely known that terms such as 'wheezing' and 'asthma' have different meanings in different languages and cultures, it may have introduced some information bias that we were unable to measure or adjust for.

Parent-reported lifetime asthma prevalence in a multiethnic, diverse sample of grades 1 and 2 children attending publicly funded schools in Toronto remains high, although the present study adds evidence that asthma prevalence in Canada may have plateaued or even decreased during the past decade, similar to other affluent countries worldwide. A large proportion of children in grades 1 and 2 with doctor-diagnosed lifetime asthma do not report current asthma symptomatology or medication use. 
ACKNOWLEDGEMENTS: The authors acknowledge the many organizations and people who made this large and complex project possible, in particular: Health Canada (funder); administrative staff, principals and teachers within The Toronto District School Board and the Toronto Catholic School Board; Lorelei Nardi (Project manager), Donna Wilkes (Research coordinator) and the many other research assistants and students involved in data collection; and the parents who took time out of their busy days to participate in the present study.

\section{REFERENCES}

1. Health Canada: Respiratory Disease in Canada. Ottawa: Health Canada, 2001.

2. To T, Dell S, Dick P, Cicutto L. The burden of illness experienced by young children associated with asthma: a population-based cohort study. J Asthma 2008;45:45-9.

3. Millar WJ, Hill GB. Childhood asthma. Health Rep 1998;10:9-21 (English);22-9 (French)

4. Burney PG, Chinn S, Rona RJ. Has the prevalence of asthma increased in children? Evidence from the national study of health and growth 1973-86. BMJ 1990;300:1306-10.

5. Ninan TK, Russell G. Respiratory symptoms and atopy in Aberdeen schoolchildren: Evidence from two surveys 25 years apart. BMJ 1992;304:873-5. (Erratum in 1992;304:1157).

6. Butland BK, Strachan DP, Anderson HR. The home environment and asthma symptoms in childhood: Two population based casecontrol studies 13 years apart. Thorax 1997;52:618-24.

7. Zollner IK, Weiland SK, Piechotowski I, et al. No increase in the prevalence of asthma, allergies, and atopic sensitisation among children in Germany: 1992-2001. Thorax 2005;60:545-8. (Erratum in 2006;61:274).

8. Anderson HR, Gupta R, Strachan DP, et al. 50 years of asthma: UK trends from 1955 to 2004. Thorax 2007;62:85-90.

9. Worldwide variations in the prevalence of asthma symptoms: The International Study of Asthma and Allergies in Childhood (ISAAC). Eur Respir J 1998;12:315-35.

10. Manfreda J, Sears MR, Becklake MR, et al. Geographic and gender variability in the prevalence of bronchial responsiveness in Canada. Chest 2004;125:1657-64.

11. Manfreda J, Becklake MR, Sears MR, et al. Prevalence of asthma symptoms among adults aged $20-44$ years in Canada. CMAJ 2001;164:995-1001.

12. Habbick BF, Pizzichini MM, Taylor B, Rennie D, Senthilselvan A, Sears MR. Prevalence of asthma, rhinitis and eczema among children in 2 Canadian cities: The International Study of Asthma and Allergies in Childhood. CMAJ 1999;160:1824-8.
13. Asher MI, Montefort S, Bjorksten B, et al; Group IPTS. Worldwide time trends in the prevalence of symptoms of asthma, allergic rhinoconjunctivitis, and eczema in childhood: ISAAC phases one and three repeat multicountry cross-sectional surveys. Lancet 2006;368:733-43.

14. Asher MI, Keil U, Anderson HR, et al. International Study of Asthma and Allergies in Childhood (ISAAC): Rationale and methods. Eur Respir J 1995;8:483-91.

15. The International Study of Asthma and Allergies in Childhood. $<$ http://isaac.auckland.ac.nz/> (Version current at November 23, 2009).

16. Selected trend data for Toronto (City) , 2006, 2001 and 1996 censuses. <http://www12.statcan.ca/english/census06/data/trends/ Table_1.cfm?TID $=0 \&$ T $=$ CSD\&PRCODE $=35 \&$ GEOCODE $=20005$ \&geosubCSD $=$ Submit $\&$ GEOLVL $=\mathrm{CSD}>$ (Accessed on November 23, 2009).

17. To T, Wang C, Dell S, Fleming-Carroll B, et al. Risk Factors for repeat adverse asthma events in children after visiting an emergency department. Amb Pediatr 2008;8:281-7.

18. The International Study of Asthma and Allergies in Childhood: Phase 1 Manual < http://isaac.auckland.ac.nz/phases/phaseone/ phaseonemanual.pdf $>$ (Accessed on January 21, 2010).

19. Ontario Ministry of Education: Number of schools in the city of Toronto that reported enrolment in 2005-2006. In: Foty R, ed. Proportion of schools in Toronto that belong to the Catholic and Public School Boards Edition. Toronto, 2008.

20. Statistics Canada: 2001 Census handbook. Ottawa, Ontario 2001.

21. Statistics Canada: National Longitudinal Survey of Children and Youth (NLSCY/KIDS), Cycle 5 (2002-2003): Self-Administered Questionnaire file. Ottawa: Statistics Canada and Human Resources Development Canada, 2003.

22. Statistics Canada. Diagnosis of Asthma by a Health Professional by Sex of Child, Children Aged 5 to 9 Years of Age Living in the Toronto CMA (based on 1996 Census), National Longitudinal Survey of Children and Youth, Cycle 4 (2000-01). Special Tabulation, 2008.

23. Statistics Canada. PMK's and Spouse's Smoking Status for Children Aged 5 to 9 Years of Age Living in the Toronto CMA (based on 1996 Census), National Longitudinal Survey of Children and Youth, Cycle 4 (2000-01). Special Tabulation, 2008.

24. Stein RT, Sherrill D, Morgan WJ, et al. Respiratory syncytial virus in early life and risk of wheeze and allergy by age 13 years. Lancet 1999;354:541-5.

25. Jenkins MA, Clarke JR, Carlin JB, et al. Validation of questionnaire and bronchial hyperresponsiveness against respiratory physician assessment in the diagnosis of asthma. Int J Epidemiol 1996;25:609-16.

26. Pearce N, Beasley R, Pekkanen J. Role of bronchial responsiveness testing in asthma prevalence surveys. Thorax 2000;55:352-4.

27. To T, Vydykhan TN, Dell S, Tassoudji M, Harris JK. Is obesity associated with asthma in young children? J Pediatr 2004;144:162-8. 


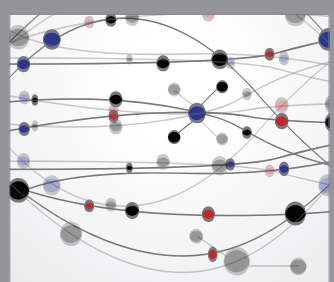

The Scientific World Journal
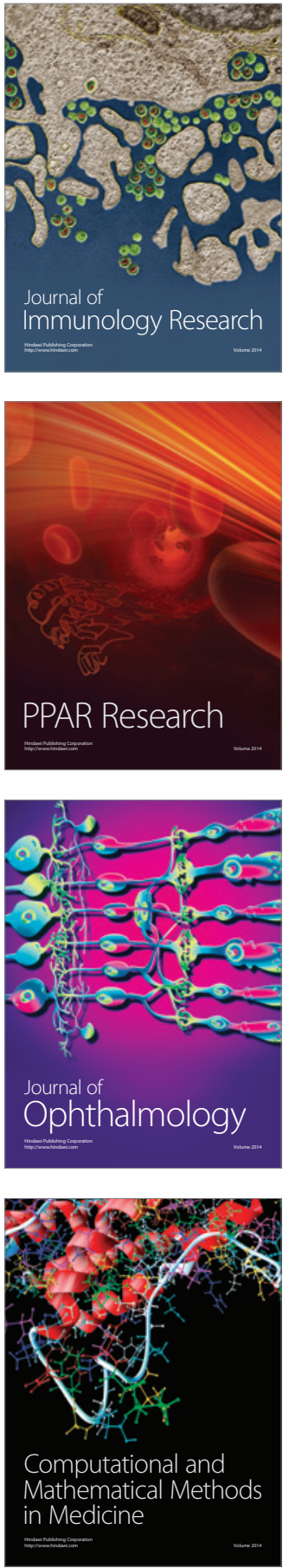

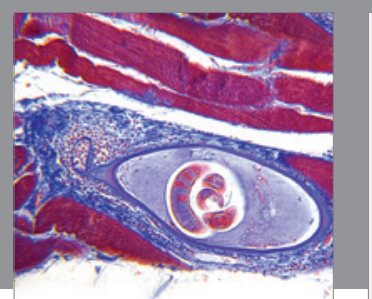

Gastroenterology Research and Practice

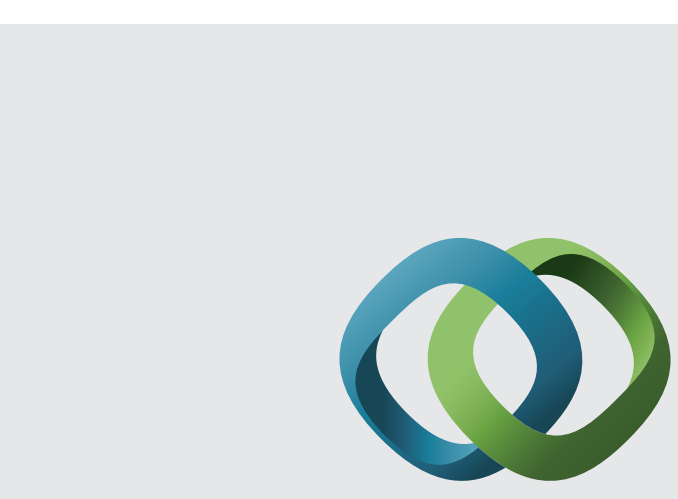

\section{Hindawi}

Submit your manuscripts at

http://www.hindawi.com
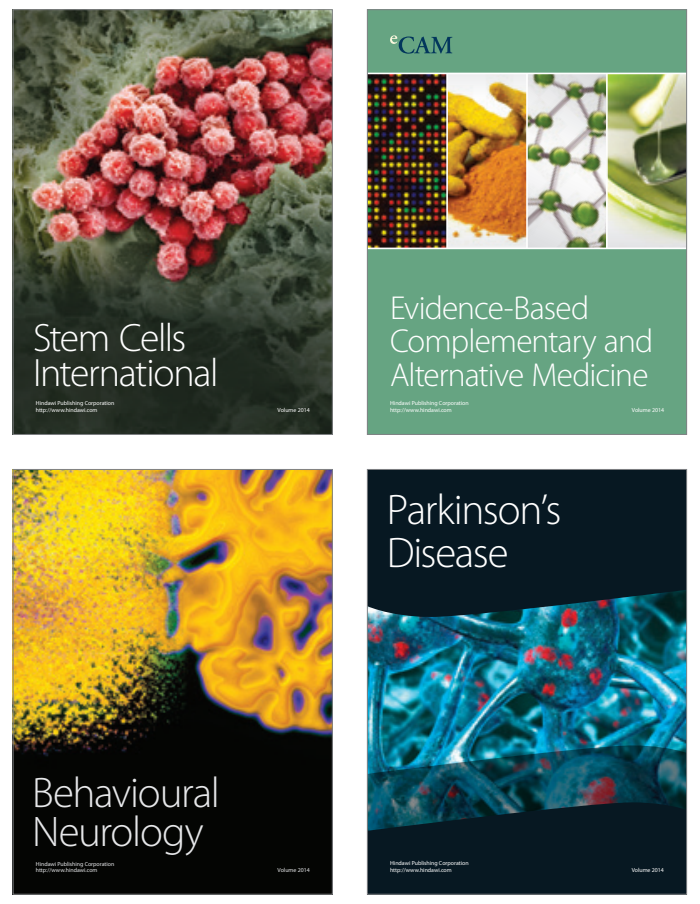
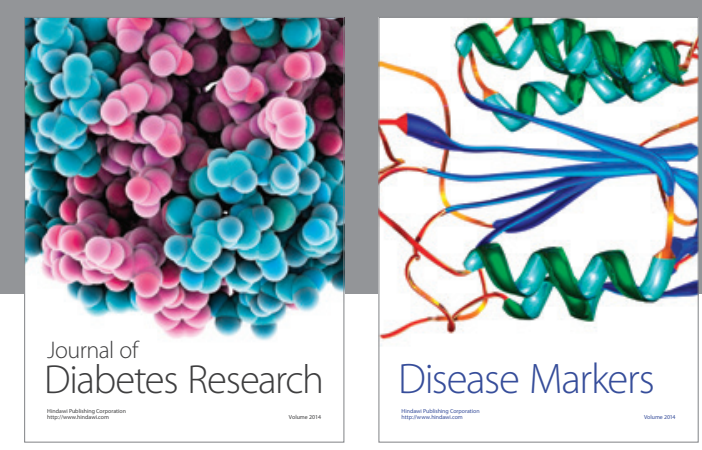

Disease Markers
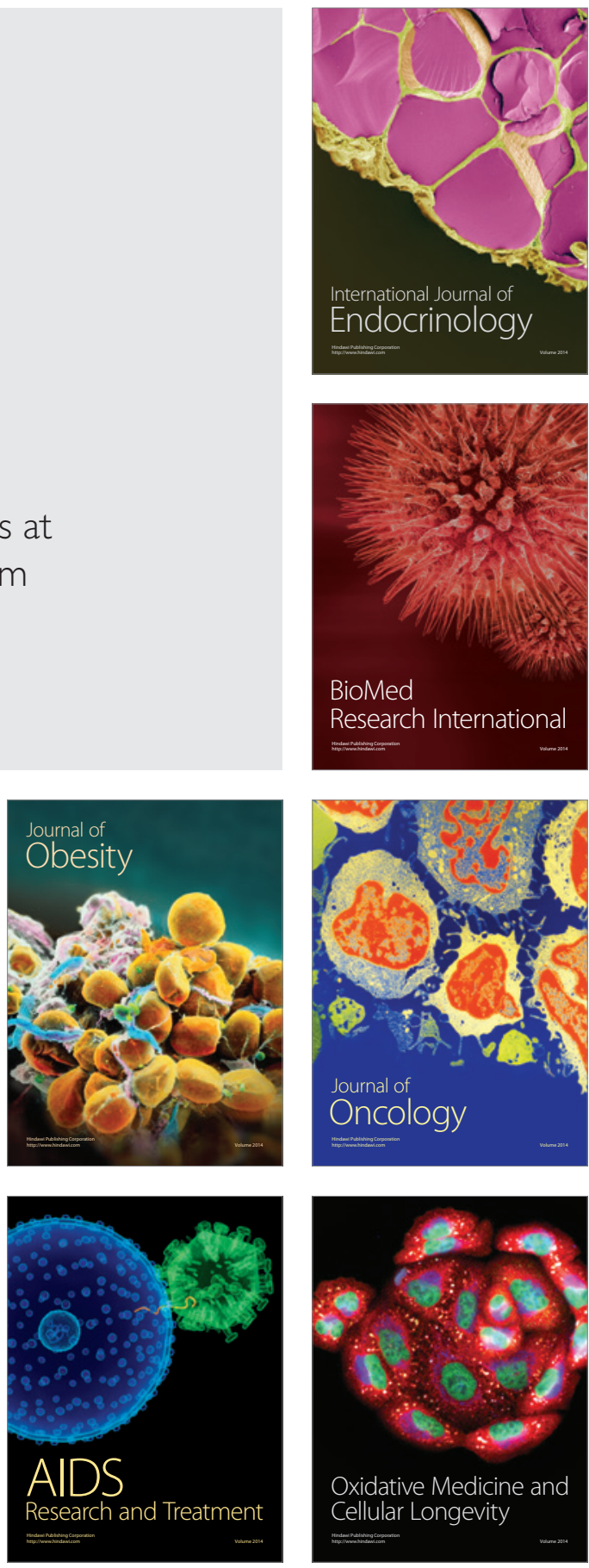